Florida International University FIU Digital Commons

$4-4-2000$

\title{
Countering the consideration of extra-legal factors in damage award decisions
}

Tracey Renee Carpenter

Florida International University

DOI: $10.25148 /$ etd.FI14052582

Follow this and additional works at: https://digitalcommons.fiu.edu/etd

Part of the Psychology Commons

\section{Recommended Citation}

Carpenter, Tracey Renee, "Countering the consideration of extra-legal factors in damage award decisions" (2000). FIU Electronic Theses and Dissertations. 2052.

https://digitalcommons.fiu.edu/etd/2052 


\title{
FLORIDA INTERNATIONAL UNIVERSITY
}

Miami, Florida

\section{COUNTERING THE CONSIDERATION OF EXTRA-LEGAL \\ FACTORS IN DAMAGE AWARD DECISIONS}

\author{
A thesis submitted in partial fulfillment of the \\ requirements for the degree of \\ MASTER OF SCIENCE \\ in \\ PSYCHOLOGY \\ by \\ Tracey Renee Carpenter
}


To: Arthur W. Herriott

College of Arts and Sciences

This thesis, written by Tracey Renee Carpenter, and entitled Countering the Consideration of Extra-Legal Factors in Damage Award Decisions, having been approved in respect to style and intellectual content, is referred to you for judgment.

We have read this thesis and recommend that it be approved.

Margaret Bull Kovera

Mary Volcansek

Gary Moran, Major Professor

Date of Defense: April 4, 2000

The thesis of Tracey Renee Carpenter is approved.

Dean Arthur W. Herriott College of Arts and Sciences

Dean Richard L. Campbell Division of Graduate Studies

Florida International University, 2000 


\section{ACKNOWLEDGMENTS}

I would like to thank my committee for their help and support. You were very patient with me and extremely accommodating which I truly appreciate. I would also like to thank Veronica Stinson for catching my mistakes and leading me in the right direction. I cannot imagine what I would have done without your help.

I would also like to thank Judge Andrews and the Broward County Clerks office. No only did they allow me to infringe on their time to collect my data, but they provided tremendous help in making sure the process was a smooth one. Their kindness is very much appreciated. 


\author{
ABSTRACT OF THE THESIS \\ COUNTERING THE CONSIDERATION OF EXTRA-LEGAL \\ FACTORS IN DAMAGE AWARD DECISIONS. \\ by \\ Tracey Renee Carpenter \\ Florida International University, 2000 \\ Miami, Florida \\ Professor Gary Moran, Major Professor
}

Compensatory and punitive awards were created to serve two separate and distinct purposes: to compensate the plaintiff for his/her injuries and to punish the defendant for negligent conduct, respectively. Thus, defendant characteristics should have no impact on compensatory award decisions. Extensive research, however, indicates that these extra-legal factors do impact damage awards. The purpose of this study was to examine whether varying types of judicial instructions could be used to reduce the effects of such extra-legal considerations, particularly a defendant's status as an individual or a corporation and defendant reprehensibility. As hypothesized, participants awarded larger compensatory awards in high reprehensibility conditions than in low reprehensibility conditions. There was also a trend to award larger sums of money when the defendant was a corporation rather than an individual. However, none of the four levels of judicial instructions were shown to counter the impact of either extra-legal consideration. 
TABLE OF CONTENTS

CHAPTER

PAGE

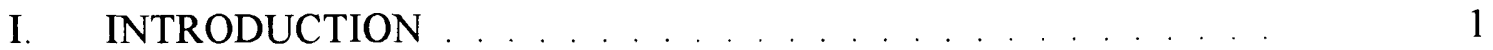

II. LITERATURE REVIEW. . . . . . . . . . . . . . . . . . . . . . . . . 2

III. METHODOLOGY. . . . . . . . . . . . . . . . . . . . . . . . . . . . . . . . $\quad 14$

Participants. . . . . . . . . . . . . . . . . . . . . . . $\quad 14$

Materials and Design. . . . . . . . . . . . . . . . . . . . . . . . . . . . 14

Procedure. . . . . . . . . . . . . . . . . . . . . . 16

IV $\quad$ RESULTS . . . . . . . . . . . . . . . . . . . . . . . 16

V. DISCUSSION . . . . . . . . . . . . . . . . . . . . . . 17

LIST OF REFERENCES . . . . . . . . . . . . . . . . . . . . . . . . . 21

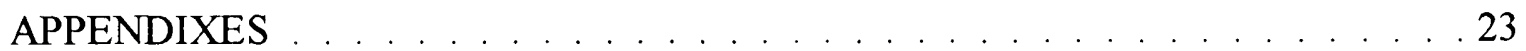




\section{Countering the Consideration of Extra-Legal}

Factors in Damage Award Decisions

There has been extensive controversy concerning the intricacies of juror decisionmaking. One area of focus in that controversy has been civil damage awards. Many argue that this is an area in which jurors are allowed too much latitude and must make important decisions based upon ambiguous instructions. In addition to producing great variation among award amounts, such ambiguity leaves these award decisions open to the effects of extra-legal influences. There is an abundance of evidence demonstrating that jurors consider extra-legal factors when making damage award decisions (Wasserman \& Robinson, 1980; Hans \& Ermann, 1989; MacCoun, 1996).

As defined by the legal system, compensatory damages are intended to compensate the plaintiff for any suffered losses. The purpose of this type of award is to bring the plaintiff back to the place where he/she was before the accident. Therefore, this type of award should be based solely on the degree of injuries suffered by the plaintiff. Defendant characteristics should have no impact on the amount of the compensatory award. Ideally, two similar plaintiffs who suffered from similar injuries would receive similar compensatory damage awards independent of the identity or status of the defendant. The same accident, leading to the same injuries, should theoretically produce the same compensatory damages across defendants. This means that similar damages should be awarded regardless of factors such as, whether the defendant is a corporation or an individual, the reprehensibility of the defendant's conduct, or the defendant's ability to pay a large sum.

Punitive damages, on the other hand, are intended to serve as punishment for wantonly negligent or reckless behavior. This type of damages should consider only the conduct and characteristics of the defendant and should ignore the needs and characteristics of the plaintiff. The severity of the plaintiff's injuries should have no 
impact on the amount of the punitive award. Therefore, if defendant conduct is held constant across cases then punitive award amounts should be the same, independent of the plaintiff's needs or injuries.

In spite of the legal distinction between the two types of damage awards and their differing purposes, jurors generally receive little or no instruction as to how damage award decisions should be made. Typically, jurors receive no guidelines as to what factors are appropriate or inappropriate to consider. This study examines whether additional instructions lead to more legally sound award decisions. Specifically, do additional instructions that explicitly state what factors are to be considered when making such decisions reduce the jurors consideration of extra-legal factors? The extra-legal factors examined in this experiment are defendant status as a corporation or an individual and the reprehensibility of the defendant's conduct.

Chin and Peterson (1985) questioned whether justice is actually blind to factors not related to the case in question. The researchers examined verdict data for over 9,000 civil cases in Cook County, Illinois. Their purpose was to determine if, in reality, there are plaintiffs that are more likely to win (irresistible plaintiffs) or defendants that are more likely to have large damage awards levied against them (deep pocket defendants). The deep pocket theory proposes that jurors award larger amounts against defendants that appear to have more money. Therefore, simply because a defendant has a greater ability to pay, he will be required to pay larger amounts. Until this point, the idea that such factors impacted verdicts and damage awards had been liberally claimed, but not empirically tested.

Based on the Cook County data, Chin and Peterson (1985) did find evidence for the deep pocket effect. Amounts awarded against corporations were higher than those awarded against individuals. The authors, however, did point out that the cases involving corporate defendants also differed from the cases involving individual defendants on 
other dimensions. Corporate defendants were more likely to be involved in high stakes cases and cases with multiple defendants. Using statistical analyses to control for those factors, a corporate/individual difference was still found. Damage awards were higher against corporations when the plaintiff suffered injuries that were not severe, but in cases of severe injuries the difference became much larger.

A regression model based on the verdict data collected in Cook County, Illinois, was developed by Hammitt, Carol, and Relles (1985). This model predicts strong differences in award amounts between suits filed against corporations and suits filed against individuals. After taking injury and case type into account, the authors predict that awards against corporations will be 34 percent larger than awards against individuals. This difference is even more pronounced in cases in which the plaintiff suffers severe and permanent injuries. In these instances, awards against corporations are predicted to be 4.5 times higher than awards against individuals.

As is previously summarized, past research in this area has focused on the examination of archival data. Though useful, such examinations do not provide experimenters with the control available in laboratory research. One difficulty encountered in using procedures involving archival data is the inability to equivocate the cases. An experimental design allows the experimenter to control all aspects of the case and manipulate only the identity of the defendant. Actual cases, on the other hand, will rarely be so clean-cut. In addition to defendant identity, many other case-unique characteristics are introduced. The abundance of such additional characteristics render it difficult to detect what factors are actually causing the differences and dangerous to draw too many conclusions based on archival data.

Vidmar (1994) warns experimenters of just such errors. Although data of this type provides certain useful information, Vidmar (1994) suggests that experimenters resist being drawn to archival data merely because it pertains to "real" cases. The author 
warns of the numerous dangers involved in relying solely on research of archival data. Not only is it impossible to eliminate alternate hypotheses, but often cases from different jurisdictions differ on so many dimensions that the cases are no longer even comparable. These problems underscore the need for laboratory research demonstrating the same corporate/individual difference found in archival data.

Wasserman and Robinson (1980) conducted a laboratory study examining this issue. The authors were interested in the effects of nonevidentary influences, particularly defendant identity and type of evidence, on damage awards. The experimenters asked participants to award damages in a case in which the defendant was described either as an average man earning about $\$ 30,000$ a year, or an average corporation with assets of about $\$ 2$ million. After making individual award decisions, participants were placed into groups and asked to deliberate and reach a group award decision. Both individual and group mean awards were higher against the corporate defendant than against the individual defendant.

A caveat to the authors' conclusions must be noted. The description in the individual condition contained the information that the individual did not have an insurance policy. No such information was given for the corporate defendant. Both defendant status and insurance coverage or lack thereof are extra-legal influences and neither should theoretically affect award decisions. For this reason, the evidence does demonstrate that mock jurors are considering extra-legal factors when making their decisions. However, it can not be concluded from this study that the large differences in award amounts are due to a difference in defendant status, as the author asserts, rather than to the issue of insurance coverage.

An interest in examining differences in public attitudes concerning corporate and individual wrongdoing led Hans and Ermann (1989) to conduct a study that lends support to the corporate versus individual bias. The authors constructed two scenarios describing 
workers who developed illnesses after being contracted to perform a job. As a result the workers brought legal action against the party that hired them. The scenarios were identical except for the identity of the defendant. Half of the participants received scenarios in which the defendant was Mr. Jones, the other half, the Jones Corporation. Participants were asked to determine liability, damages, and criminal negligence.

Findings in all three categories supported a bias against corporations (Hans \& Ermann, 1989). The Jones Corporation was significantly more likely to be found liable for plaintiff injuries. Once liability had been established, larger damage awards were awarded against the corporate defendant than the individual defendant. This difference was particularly large for pain and suffering damages, which is the category in which jurors have the most freedom in their award decision. In addition, Mr. Jones was much less likely then the Jones Corporation to be voted as criminally negligent.

Further attitudinal questions revealed that participants regarded lawsuits against the corporation as both more fair and more reasonable than the lawsuits against the individual. Criminal charges were also viewed as more fair when they were brought against the Jones Corporation than when they were filed against Mr. Jones. Participants rated the degree of harm suffered by the workers as the same across groups, but perceived the actions of the corporate defendant as much more sinister than the actions of the individual defendant. The corporate defendant was found to be "more reckless, more morally wrong, and more deserving of punishment" than the individual defendant (Hans \& Ermann, 1989, p. 158). Corporations were also rated as more likely to have previously been aware of the dangers, less regretful after the incident, and less likely to change their behavior in the future.

These findings indicate that award discrepancy between corporate and individual defendants is due to something more intricate than the defendant's ability to pay. Although the corporation was seen as having a greater ability to pay awarded damages, 
this was far from the only difference found between the two defendants (Hans \& Ermann, 1989). The fact that the corporation was generally viewed in a more negative light than the individual, despite the fact that all case characteristics were identical, suggests that the public has a much harsher opinion of corporate wrongdoing than of individual wrongdoing. These findings led the authors to speculate that much more than a deep pockets phenomenon was occurring. The authors propose that jurors hold corporations to a higher standard than individuals and as a result have a more negative view of corporate wrongdoing. This less lenient attitude toward corporations then leads to higher damage awards against corporate defendants.

MacCoun (1996) purports that a flaw in the studies designed to test the deep pocket hypothesis is the confound of defendant wealth and defendant identity. It is reasonable to assume that jurors may perceive corporations as more wealthy than individuals. For that reason, monetary judgments against corporations may be higher based on a higher perceived ability to pay rather than as a result of a bias against corporate defendants. This idea is consistent with the deep pocket hypothesis. MacCoun (1996) points out that studies that merely compare corporations and individuals cannot eliminate the possibility that the award disparity may be a sole function of perceived wealth or ability to pay. On the other hand, the disparity may be independent of defendant wealth and be attributable to differing perceptions of corporations and individuals.

In a study designed to further test the deep pockets phenomenon, MacCoun (1996) examines whether the noted differences are actually due to the wealth of the defendant, as the deep pocket theory would suggest, or instead to the individual/corporate distinction. In an effort to eliminate this confound, MacCoun (1996) created a design that included three defendant conditions: a blue-collar individual, a wealthy individual, and a corporate defendant. Defendant descriptions for the wealthy individual and the corporate 
defendant held all characteristics constant except the name of the defendant. For example, one case described the defendants as a construction worker (blue-collar defendant), the owner of a "construction contracting business with many concurrent projects and a large crew of construction workers" (wealthy individual defendant), or a corporation that is a "construction contracting business with many concurrent projects and a large crew of construction workers" (corporate defendant) (MacCoun, 1996).

Controlling for defendant wealth, MacCoun (1996) found that mock jurors still gave larger damage awards when the defendant was a corporation, rather than an individual. This bias against corporations occurred even when the individual was described as a wealthy individual with the same assets as the corporation. These findings are not consistent with the deep pocket hypothesis, which has previously been used to explain the corporate versus individual award differential. If the award decisions were guided by the defendant's ability to pay then the judgments against the corporate defendant and the wealthy individual should be both comparable and significantly higher than the judgments against the blue-collar individual. Instead, as was the trend in past research, similar judgments were awarded to the individual defendants with higher judgments awarded against the corporation.

An empirical examination by Vidmar (1995) did not produce results consistent with the archival analyses or the previous research in this area. His experiment was designed to test the notion that medical malpractice cases are somehow treated differently than other types of cases and that this difference is attributable to the perceived "deep pockets" of insurance companies. Vidmar (1995) assigned participants to read either a malpractice or automobile negligence case that had either one defendant, two defendants, or a corporate defendant. He found no differences in mean award amounts between groups.

It is uncertain why Vidmar's (1995) findings were not consistent with past 
research. Due to the medical malpractice focus of Vidmar's (1995) study, the case descriptions were somewhat different than the scenarios used in the previously cited studies. These differences may have somehow influenced award amounts. In the corporate conditions, the cases depended on the legal doctrine of vicarious liability in which employers are responsible for the actions of their employees. Additionally, the cases were such that in the individual conditions, the defendants actually committed a negligent act. The injuries were not due to improper corporate policies, but rather due solely to the actions of the individual. Therefore, it was not actually the corporation that committed the injurious act, although the corporation was legally responsible for it. Under these circumstances, it is not terribly difficult to imagine that the previously documented difference may be alleviated by a desire to award larger damages against a defendant that directly committed the act and less against a corporation that was indirectly responsible for it. However, the award differences found by MacCoun (1996) were consistent across six different cases, some of which involved the issue of vicarious liability.

There could be numerous reasons why damage award decisions against corporations are higher than those against individuals. As suggested by Hans and Ermann (1989), the difference could be attributable to corporations being held to a higher standard. The attribution theory can account for such a difference in standard. A corporation is composed of a number of people. A group of people, due to their collective resources, may be expected to have greater foresight about such matters than an individual (Hans \& Ermann, 1989). Additionally, it may be easier for jurors to award large damages against corporations because it is a more impersonal entity than an individual (MacCoun, 1996). Along the same lines, Hammitt et al. (1985) suggests that jurors may be balancing the good that the money will do the plaintiff against the harm that paying the awarded amount will do to the defendant. It may be easier for jurors to 
perceive the award as harmful when it is against an individual than when it is against a corporation.

Regardless of the reason behind this effect, the defendant's status as a corporation or individual is a factor that has been shown to be a consideration for the purposes of awarding compensatory damages. As previously stated, this runs counter to the legal purpose of compensatory damages. Compensatory damages should be based solely on the plaintiffs injuries and suffering and should not be influenced by defendant characteristics.

It is also important to perform a conceptual replication of these findings using a different characteristic to ensure that these results are not due to something unique in the corporation/individual characteristic. Another extra-legal factor that may affect damage award decisions is defendant reprehensibility. Cather, Greene, and Durham (1996) designed a study to investigate whether jurors were basing their damage award decisions on the appropriate legal factors. The experiment examined the effects of plaintiff injury and defendant reprehensibility on award decisions. In accordance with legal doctrine, plaintiff injury should impact compensatory damages, but not punitive damages. The opposite trend should be true for defendant reprehensibility; reprehensibility should affect punitive awards, but not compensatory awards. Participants were given brief instructions as to the purpose of each type of damages. Although Cather et al. (1996) did not find a significant difference between awards for high versus low reprehensibility of defendants, there was a definite trend in that direction. Across three cases, the mean award amount for highly reprehensible defendants was $\$ 413,000$ as opposed to $\$ 196,000$ for less reprehensible defendants.

Further evidence in this regard is provided by Wissler, Evans, Hart, Morry, and Saks (1997). Wissler et al. (1997) examined how fault attributions affected pain and suffering awards. The authors manipulated the degree of defendant fault and found 
marginally significant differences $(p=.067)$ for pain and suffering awards between groups across the five case scenarios. In addition, for one of the five cases, there were strong differences between award amounts for very responsible versus less responsible defendants $(\mathrm{p}<.001)$. This indicates that weaker findings may be due to weaker manipulations or factors specific to the given case summary.

The Hans and Ermann (1989) experiment also lends support to the notion that defendant reprehensibility influences compensatory award decisions. The authors assert that these differences may be due to corporations being held to a higher standard than individuals. Based on this standard, identical actions may be considered more reckless when committed by a corporation than by an individual. Consistent with that idea, the conditions in which mock jurors awarded high damages were also the conditions in which the respondents considered the defendant to be most reckless.

Consideration of the evidence indicates that despite what is legally intended, extra-legal factors do play a role in damage award decisions. An interesting question then becomes, "How can such considerations be countered?" As has been previously stated, jurors are placed into a role in which they are asked to make extremely important decisions, but are given very little guidance. Guidance as to what should or should not be considered when making damage decisions is a matter dealing with juror education and bias reduction. This information could be presented with ease through judicial instructions, which are routinely used to inform and educate jurors about various legal matters.

The traditional method of dealing with factors that jurors are not supposed to consider has been to not mention or to ignore those factors. In certain instances, this is a legitimate method of bias reduction. Courts routinely withhold information from, or blindfold, juries as a means of reducing bias. Not informing jurors of a defendant's past criminal record is an example of blindfolding for that purpose. In this example, a bias 
would be very likely if the jurors were given that information and blindfolding is a logical answer. The problem, however, arises when the idea of not addressing a bias is applied in situations in which ignoring the bias does not eliminate it. There are some circumstances in which it would be more beneficial to stop ignoring that jurors may consider particular factors and instead instruct them otherwise. Not telling a jury whether a defendant in a motor vehicle accident suit carried insurance is an example of problematic blindfolding. This information is not given to jurors because it is a factor that is not supposed to be considered. However, if the matter at hand is something about which jurors already have established beliefs or expectations, then blindfolding is unlikely to serve its intended purpose (Diamond \& Casper, 1992). In this case, it is understandable that jurors may assume that the defendant has insurance though he or she may not. It is also understandable that this assumption may influence jurors damage award decisions. This illustrates the importance of recognizing and dealing with any biases that will not be corrected for by simply not addressing those issues with the jurors.

The consideration of extra-legal factors in award decisions has not been eliminated by ignoring it. Jurors must be informed that such considerations are inappropriate. In addition, explaining to jurors the purpose of each type of damages and the reasons that certain factors should not be considered should lead to better compliance with the instructions than mere admonitions not to consider those factors (Diamond $\&$ Casper, 1992).

Furthermore, in order for jurors to follow judicial instructions, the instructions must be clearly written. Clarity of judicial instructions has been studied across many legal specters. Juror's lack of understanding of judicial instructions has been evidenced in various legal circumstances. Jurors have been shown to be unclear as to the degree of certainty that is required by the reasonable doubt standard even after receiving specific judicial instructions (Horowitz \& Kirkpatrick, 1996). Additionally, Reifman, Gusick, 
and Ellsworth (1992) found that jurors understood less than half of the instructions they were given. It is therefore evident why such variation in juror decision-making exists. It is also evident that jurors are in need of clear, concise instructions. This study attempts to reduce award variation and consideration of extra-legal factors by providing jurors with brief, yet concise instructions concerning what should and should not be considered in compensatory damage award decisions.

The literature has also speculated as to the effects of including specific examples in judicial instructions. In particular, the death qualification literature raises the concern that if jurors are given a list of mitigators, they may interpret the listed mitigators as the only mitigators they are allowed to consider. This concern also arises when constructing judicial instructions as to what may and may not be considered when awarding civil damages. This study incorporates this concern into the design by creating two conditions that list examples. In one example condition, one of the factors that is being examined (corporate/individual status) will be included as an example in the list, but the other factor (defendant reprehensibility) will not. The other example condition will be the opposite. Defendant reprehensibility will be included as an example in the list, but corporate/individual status will not. All other examples in the list will remain the same. Additionally, the two variations of the example condition are needed to ensure that the instructions are not having an undesired effect. It is possible that listing factors, such as defendant's corporate status, may make that factor more salient and thus increase the chances that it will influence decision-making. This would result in an even greater disparity in awards between the two types of defendants. By creating two example conditions, one in which the defendant's status is given and one in which it is not, this possibility can be examined and ruled out.

The purpose of this study is to examine whether differing types of judicial instructions can reduce the differences in damage awards that result from the 
consideration of extra-legal factors. Consistent with past studies, it is expected that both corporate status of the defendant and defendant reprehensibility will influence compensatory and punitive award decisions. Four levels of instruction (pattern instructions, expanded instructions, and expanded instructions with examples including or not including the factor in question) will be incorporated to determine whether judicial instructions can counter the disparity in compensatory awards.

The pattern instructions typically given to jurors in civil cases, do not provide clear instruction as to what information may be employed in damage award decisions. As a result, jurors must make their decisions based on the information that they are given which has been shown to result in the improper consideration of extra-legal factors. It is understandable that in the face of unclear or confusing instructions, jurors would rely on what they know, primarily that the defendant's conduct was atrocious or that the defendant is a large or wealthy corporation. Expanding on judicial instructions should provide jurors with a better framework of how their decisions should be made and as such, redirect their attention to the allowed and pertinent considerations. As the framework becomes more clear and detailed, the reliance on extra-legal information should be lessened. Therefore, with each increase in instruction clarity, a reduction in extra-legal considerations is expected. Based on the previously mentioned evidence, the expected findings are as follows.

Hypothesis 1: Extra-legal factors, such as corporate/individual status and defendant reprehensibility, will impact compensatory damage awards when no judicial instructions not to consider those factors are given.

Hypothesis 2: Expanded instructions as to the purpose of each type of damages are not sufficiently clear and will not be effective in eliminating the consideration of extra-legal factors in damage award decisions.

Hypothesis 3: The addition of examples to the expanded instructions will provide 
more clear and concise instruction for jurors and will reduce the consideration of extra-legal factors in damage award decisions. This will occur regardless of whether the extra-legal factors present in the case scenario are listed in the example list.

\author{
Method
}

\title{
Participants
}

With the help of the Broward County clerk, one hundred eighty-two volunteers were recruited from the jury pool in Broward County, Florida between January, 2000 and March, 2000. Fifty-two percent of the participants were male, 79\% Caucasian, 10\% Hispanic, and 10\% African American. The median age of the sample was 50-59 and the median annual household income was $\$ 45,000-\$ 60,000$.

\section{Materials and Design}

This experiment incorporated a 2 X 2 X 4 (Corporate Status X Reprehensibility X Instruction Type) between-subjects, fully-crossed design in which each participant received one level of each independent variable. The survey consisted of a civil case summary followed by a brief questionnaire. The summary described a personal injury civil court case in which an individual was injured when a shelf collapsed on him as he was browsing in a hardware store (see Appendix A). The materials included the information that a determination of liability had been made. This information was followed by a request to award compensatory and punitive damages based upon the information provided in the summary. Judge's instructions were given to guide the participants in their decision-making. As is the practice in actual cases, the survey allowed the participants to award compensatory damages in individual categories. The four compensatory award categories included in this experiment were as follows: medical expenses, loss of wages, pain and suffering, and loss of capacity for the enjoyment of life. This was followed by an opportunity to award punitive damages. 
Attached was a two-page questionnaire composed of 9-point Likert scale-type opinion and attitude items concerning the case and the litigants followed by a basic demographic questionnaire (see Appendix C).

All information concerning the plaintiff, the incident in question, and the injuries sustained remained constant across conditions. The case scenarios between conditions differed on three dimensions: the status of the defendant (corporation or individual), the degree of defendant reprehensibility, and the type of judicial instructions. Half of the respondents received a summary in which the defendant was identified as Mr. Maxwell. The other half of the participants received questionnaires that identified the defendant as Maxwell Corporation. There were two reprehensibility levels, high and low, which were manipulated by altering the defendant's pre-accident conduct (what precautions were taken, what policies were held and followed, etc.).

The manipulation of judge's instructions was divided into four levels (see Appendix B). The first level provided basic judicial instructions with no instructions as to what could and could not be considered when determining damage awards. These instructions were taken from the pattern instructions that jurors are currently given in this type of case and as such served as a baseline as to the information on which jurors are currently basing their award decisions. In addition to the information given in the first level of instructions, the second level provided more in-depth guidelines as to what were proper and improper considerations for each type of damage award. However, this level of instruction gave no examples of those considerations. The third and fourth levels provided the pattern instructions from the first level, the in-depth guidelines from the second level, and gave examples of what type of considerations were inappropriate. One of the example levels included whether the defendant was a corporation or individual as an example in the example list, but did not include defendant reprehensibility. Likewise, the other example level included defendant reprehensibility as an example in the example 
list, but did not include corporate status of the defendant.

\section{Procedure}

The experimenter was allowed to recruit participants from the excess venirepersons that remained in the jury pool at the end of each day. Participants were advised that a study was being conducted for educational purposes and that the goal of the study was to examine jury decision-making, particularly in civil cases. They were informed that their participation was completely voluntary and were told that they would be asked to read a civil case summary, award damages based upon that summary, and complete a short questionnaire. Participants were randomly assigned to groups (with 1113 persons in each group) and given a complete questionnaire. After completing the questionnaire, participants were allowed to ask the experimenter questions and when any questions had been answered, participants were thanked and excused.

\section{Results}

Compensatory damage award data was analyzed using a 2 X 2 X 4 (Corporation $\mathrm{X}$ Reprehensibility X Instruction Type) analysis of variance (ANOVA). As was previously stated, the compensatory damage awards were broken down into four categories. For the purpose of analysis, those categories were summed to form a total compensatory award which was used as the dependent measure. The analysis demonstrated a significant main effect for defendant reprehensibility $(F=5.826, p<.01)$, with a mean compensatory award for high reprehensibility $(M=\$ 706,164.30)$ significantly higher than the mean compensatory award for low reprehensibility $(M=\$ 420,294.03)$. There was also a marginal main effect for status as a corporation or individual $(\mathrm{F}=3.174, \mathrm{p}<.077)$, with a mean compensatory award for corporate defendants $(\mathrm{M}=\$ 668,731.06)$ higher than the mean compensatory award for individual defendants $(M=\$ 457,727.27)($ see Appendix D). There was no main effect for instruction type and no interactions were significant. 
A 2 X 2 X 4 (Corporation X Reprehensibility X Instruction Type) analysis of variance (ANOVA) was also used to analyze punitive damage awards. As in the compensatory analysis, there was a significant main effect for defendant reprehensibility, $\mathrm{F}=8.293, \mathrm{p}<.005$, with a mean punitive award for high reprehensibility $(\mathrm{M}=\$ 559,930.87)$ significantly higher than the mean punitive award for low reprehensibility $(\mathrm{M}=\$ 27,357.96)$. In addition, the main effect for defendant's status as a corporation or individual was also significant, $\mathrm{F}=4.203, \mathrm{p}<.042$, with a mean punitive award for corporate defendants $(M=\$ 483,210.23)$ higher than the mean punitive award for individual defendants $(\mathrm{M}=\$ 104,078.60)$ (see Appendix D). Again, no main effects for instruction type were found. This analysis did demonstrate a marginally significant Corporation $X$ Reprehensibility interaction, $F=3.234, p<.074$. No other interactions were significant.

\section{Discussion}

As expected, both the defendant's status as a corporation or an individual and the degree of defendant reprehensibility were shown to effect punitive damage awards. Punitive awards were higher when the defendant was a corporation as opposed to an individual. Higher awards were also given against more reprehensible defendants as opposed to less reprehensible defendants. The highest mean punitive awards were awarded when the defendant was identified as a corporation whose conduct was highly reprehensible. This demonstrates that mock jurors are considering defendant characteristics when making punitive award decisions. This is consistent with the legally intended purpose of punitive awards, which is to punish defendants for negligent conduct. It is both a reasonable and a desirable effect to see that defendants who act in a more reprehensible manner will be punished with higher damage awards.

However, the results also indicate that mock jurors also consider these defendant characteristics when awarding compensatory damages. This finding is not consistent 
with the legally intended purpose of compensatory awards, which is solely to make the plaintiff whole again. Participants awarded higher compensatory damages when the defendant was a corporation rather than an individual, and when the defendant's actions were highly reprehensible. In essence, the mock jurors seem to be using both types of damages to punish the defendants for the incident. This occurred even in conditions in which the mock jurors received instructions not to consider defendant characteristics and were given those specific characteristics as examples of improper considerations. None of the instructions employed corrected for jurors' extra-legal considerations.

These results indicate that jurors tend to consider the same factors when making each type of award decision, despite the fact that the categories of damages were created to serve separate purposes. Judicial instructions did not correct this problem - a finding that is not surprising in the light of judicial instruction research in the areas of pretrial publicity and instructions to ignore inadmissible evidence. It still appears that jurors either do not understand or choose to ignore the differing purposes of each type of award and what factors they should consider when making each award decision. It is possible that the instructions were not carefully read or did not provide sufficiently clear explanations as to how the decisions should be made. As an oversight of the experimenter, instruction comprehension was not measured. For this reason, it is not possible to determine whether the participants even read the instructions, much less understood and attempted to follow them. It would be interesting to examine whether more in-depth instructions could succeed in clarifying jurors' misunderstandings in this regard.

It was hypothesized in this experiment that if jurors understood that the two types of damages were developed to serve separate purposes and thus were made to be based on separate considerations, then they would be more likely to make more legally sound decisions. This hypothesis was based on the intuitive, yet empirically unfounded premise 
that education on the law would lead to a higher standard in upholding the law.

However, contrary to the previous optimism of the experimenter, judicial instructions have not been shown to have considerable impact in jury decision-making.

Another explanation for the failure of judicial instructions to have an effect may be seen by examining the type of task the jurors are asked to perform. It is generally accepted that jurors take their duty very seriously and are quite motivated to make the right decision. However, by asking jurors to fully compartmentalize these two award types and maintain full control over what aspects of the case affect their decision-making, the courts may be asking jurors to complete a task that simply is not within human abilities. If that is the case and it is impossible for persons to set such clear mental boundaries as to what influences their decisions, then regardless of instruction clarity, the consideration of extra-legal factors will not be eliminated.

Judicial instructions are the most plausible method available to correct for extralegal considerations. Studies incorporating a stronger manipulation of judicial instructions can determine whether that method will be fruitful. Further studies are needed to determine if it is indeed possible to correct for the consideration of such factors. Allowing attorney's an extended voir dire in an attempt to further educate jurors on this matter is another method that may be tested. If it is found that individuals are unable to make decisions not influenced by these factors, even when they have a clear understanding of how the decisions should be made, then even the most eloquent and concise judicial instructions or the most intense voir dire will have no bearing on award decisions.

Upon further examination, it may be discovered that the courts are, in essence, asking jurors to do the impossible. If that is the case, less traditional methods of bias reduction, must be sought out and tested. One such less traditional method would be to assign separate juries to make each type of award decision with each jury being given 
only the information that they are legally allowed to consider in making their decision. In addition, it may be found that the best way to eliminate or control for the bias may be to collapse the compensatory and punitive damage awards into a single type of damage award in which all of the pertinent factors may be considered. 


\section{References}

Cather, C., Greene, E., \& Durham, R. (1996). Plaintiff injury and defendant reprehensibility: Implications for compensatory and punitive damage awards. Law and Human Behavior, 20 (2), 189-205.

Chin, A. \& Peterson, M. A. (1985). Deep Pockets, Empty Pockets: Who Wins in Cook County Jury Trials. Santa Monica, CA: RAND Corporation.

Diamond, S. S., \& Casper, J. D. (1992). Blindfolding the jury to verdict consequences: Damages, experts, and the civil jury. Law and Society Review, 26 (3), 513-563.

Hammitt, J. K., Carroll, S. J., \& Relles, D. A. (1985). Tort standards and jury decisions. Journal of Legal Studies, 14, 751-762.

Hans, V. P. \& Ermann, M. D. (1989). Responses to corporate versus individual wrongdoing. Law and Human Behavior, 13 (2), 151-166.

Horowitz, I. A., \& Kirkpatrick, L. C. (1996). A concept in search of a definition: The effects of reasonable doubt instructions on certainty of guilt standards and jury verdicts. Law and Human Behavior, 20 (6), 655-670.

MacCoun, R. J. (1996). Differential treatment of corporate defendants by juries: An examination of the "deep-pockets" hypothesis. Law and Society Review, 30 (1), 121161.

Reifman, A., Gusick, S. M., \& Ellsworth, P. C. (1992). Real jurors understanding of the law in real cases. Law and Human Behavior, 16 (5), 539-554.

Vidmar, N. (1994). Making inferences about jury verdict behavior from jury verdict statistics: Cautions about the Lorelei's Lied. Law and Human Behavior, 18(6), 599-617.

Vidmar, N. (1995). Medical Malpractice and the American Jury. Ann Arbor, MI: The Univeristy of Michigan Press.

Wasserman, D. T., \& Robinson, J. N. (1980). Extra-legal influences, group processes, and jury decision-making: A psychological perspective. North Carolina Central Law Journal, 12, 96-159.

Wissler, R. L., Evans, D. L., Hart, A. J., Morry, M. M., \& Saks, M. J. (1997) Explaining "pain and suffering" awards: The role of injury characteristics and fault attributions. Law and Human Behavior, 21 (2), 181-207. 


\section{Appendix A}

\section{Case Scenario}

The following excerpt provides information about a civil court case. Please read the information carefully and answer the questions that follow.

Richard Davis, a 43 year-old contractor, was doing business at Maxwell's Hardware. As he was comparing items from an upper shelf, several shelves collapsed on Mr. Davis, resulting in severe and permanent injuries. As a result of the accident, Mr. Davis, who previously earned about $\$ 40,000$ per year, incurred $\$ 15,000$ in medical bills and now has difficulty working. Thus, Mr. Davis brought a lawsuit against Maxwell's Hardware.

Maxwell's Hardware is owned by the defendant [corporation], Mr. Charles Maxwell [Maxwell Corporation]. Safety studies have been conducted to determine the maximum weight that can safely be placed on the shelves. Mr. Maxwell [The corporation] adhered to [ignored] the maximum weight limits and did not [routinely] overload[ed] the shelves. In addition, Mr. Maxwell [the corporation] performed periodic [has never performed any type of] safety checks to ensure that the shelves were safely mounted. 


\section{Appendix B}

\section{Levels of Instruction}

\section{$\underline{\text { Pattern Instructions }}$}

Judge's Instructions: I will now instruct you on the law you must follow in reaching your decision. The defendant has been found liable for the injuries sustained by Mr. Davis. It is now your responsibility to award Mr. Davis such sum as you find will fairly and justly compensate him for any damages he sustained as a direct result of the defendant's negligence.

In addition to any damages which you find $\mathrm{Mr}$. Davis entitled, you may, but are not required to, award Mr. Davis an additional amount as punitive damages if you find it is appropriate to punish the defendant or to deter defendant and others from like conduct in the future. Whether to award plaintiff punitive damages, and the amount of those damages, are within your discretion.

\section{Expanded Instructions}

Judge's Instructions: I will now instruct you on the law you must follow in reaching your decision. The defendant has been found liable for the injuries sustained by Mr. Davis. It is now your responsibility to award Mr. Davis such sum as you find will fairly and justly compensate him for any damages he sustained as a direct result of the defendant's negligence. The sole purpose of these damages is to make Mr. Davis whole again or return him to his state prior to the accident. This type of damages is not to be used to punish the defendant. For this reason, you may consider only the extent of Mr. Davis' needs and injuries and how these injuries will affect the remainder of his life. You may not take into consideration any characteristics of the defendant.

In addition to any damages which you find $\mathrm{Mr}$. Davis entitled, you may, but are not required to, award $\mathrm{Mr}$. Davis an additional amount as punitive damages if you find it is appropriate to punish the defendant or to deter defendant and others from like conduct in the future. Whether to award plaintiff punitive damages, and the amount of those damages, are within your discretion. This type of damages is meant to punish and deter and in making this award, you may take into account conduct and characteristics of the defendant. However, the purpose of these damages is not to further compensate the plaintiff so you should not consider the plaintiff's needs or injuries.

\section{Expanded Instructions with Reprehensibility Example}

Judge's Instructions: I will now instruct you on the law you must follow in reaching your decision. The defendant has been found liable for the injuries sustained by Mr. Davis. It is now your responsibility to award Mr. Davis such sum as you find will fairly and justly compensate him for any damages he sustained as a direct result of the defendant's negligence. The sole purpose of these damages is to make Mr. Davis whole again or return him to his state prior to the accident. This type of damages is not to be used to punish the defendant. For this reason, you may consider only the extent of Mr. Davis' needs and injuries and how these injuries will affect the remainder of his life. You may not take into consideration any characteristics of the defendant, such as the defendant's 
assets, ability to pay, or the offensiveness of the defendant's conduct.

In addition to any damages which you find Mr. Davis entitled, you may, but are not required to, award Mr. Davis an additional amount as punitive damages if you find it is appropriate to punish the defendant or to deter defendant and others from like conduct in the future. Whether to award plaintiff punitive damages, and the amount of those damages, are within your discretion. This type of damages is meant to punish and deter and in making this award, you may take into account conduct and characteristics of the defendant. However, the purpose of these damages is not to further compensate the plaintiff so you should not consider the plaintiff's needs or injuries.

\section{Expanded Instructions with Corporate/Individual Example}

Judge's Instructions: I will now instruct you on the law you must follow in reaching your decision. The defendant has been found liable for the injuries sustained by Mr. Davis. It is now your responsibility to award Mr. Davis such sum as you find will fairly and justly compensate him for any damages he sustained as a direct result of the defendant's negligence. The sole purpose of these damages is to make Mr. Davis whole again or return him to his state prior to the accident. This type of damages is not to be used to punish the defendant. For this reason, you may consider only the extent of Mr. Davis' needs and injuries and how these injuries will affect the remainder of his life. You may not take into consideration any characteristics of the defendant, such as the defendant's assets, ability to pay, or whether the defendant is an individual or a corporation.

In addition to any damages which you find Mr. Davis entitled, you may, but are not required to, award Mr. Davis an additional amount as punitive damages if you find it is appropriate to punish the defendant or to deter defendant and others from like conduct in the future. Whether to award plaintiff punitive damages, and the amount of those damages, are within your discretion. This type of damages is meant to punish and deter and in making this award, you may take into account conduct and characteristics of the defendant. However, the purpose of these damages is not to further compensate the plaintiff so you should not consider the plaintiff's needs or injuries. 


\section{Appendix C}

\section{Questionnaire}

Please answer the follow opinion items.

1. What is your opinion of the defendant?

$\begin{array}{lllllllllll}\text { Very } 1 & 2 & 3 & 4 & 5 & 6 & 7 & 8 & 9 & \begin{array}{l}\text { Very } \\ \text { Positive }\end{array} \\ \text { Negative } & & & & & & & & & \end{array}$

2. How offensive was the behavior of the defendant?

$\begin{array}{lllllllllll}\text { Very } 1 & 2 & 3 & 4 & 5 & 6 & 7 & 8 & 9 & \begin{array}{l}\text { Very } \\ \text { Positive }\end{array} \\ \text { Negative } & & & & & & & & & \end{array}$

3. How foreseeable was this accident?

$\begin{array}{lclllllllll}\text { Very } 1 & 1 & 2 & 3 & 4 & 5 & 6 & 7 & 8 & 9 & \begin{array}{l}\text { Not At } \\ \text { All Foreseeable } \\ \text { Foreseeable }\end{array}\end{array}$

4. How thorough were the precautions taken by the defendant?

$\begin{array}{lrlllllllll}\text { Very 1 } & 2 & 3 & 4 & 5 & 6 & 7 & 8 & 9 & \begin{array}{l}\text { Not At } \\ \text { All Thorough }\end{array} \\ \text { Thorough } & & & & & & & & & \end{array}$

5. How would you rate the defendant's ability to pay the awarded amount?

$\begin{array}{lllllllllll}\begin{array}{l}\text { Very } \\ \text { Able }\end{array} & 1 & 2 & 3 & 4 & 5 & 6 & 7 & 8 & 9 & \begin{array}{l}\text { Not At } \\ \text { All Able }\end{array}\end{array}$

6. How likely is it that the awarded amount will cause a financial hardship for the defendant?

$\begin{array}{lllllllllll}\begin{array}{l}\text { Very } \\ \text { Likely }\end{array} & 1 & 2 & 3 & 4 & 5 & 0 & 7 & 8 & 9 & \begin{array}{l}\text { Not At } \\ \text { All Likely }\end{array}\end{array}$

7. How suspicious are you of persons who sue?

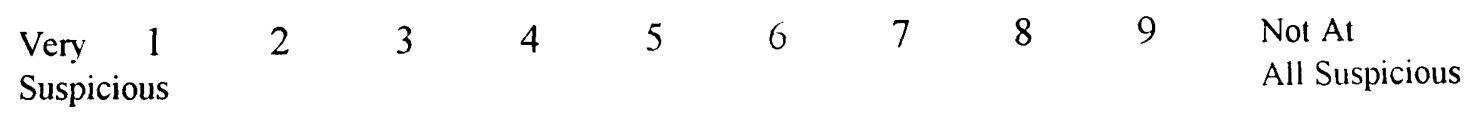

Please answer the following demographic questions.

8. Sex: Male

Female 
9. Race: White/Non-Hispanic

White/Hispanic

Hispanic/Black

Black

Other

10. Age: $18-29$

30-39

$50-59$

40-49

$60+$

11. Marital Status: 1. never married

2. divorced

3. married

4. widow/ widower

12. Education Level 1. less than high school graduate

2. high school graduate

3 . some college

4. college degree

5. post-graduate college work or degree

13. Employment Status:

1. Full-Time

2. Part-Time
3. Retired

4. Unemployed

14. Occupation:
1. Laborer
2. Sales
3. Service
4. Clerical

5. Professional

6. Student

7. Unemployed

8. Retired

15. Aside from your political affiliation, how would you evaluate your political views?

1. Liberal

2. Somewhat liberal
3. Somewhat conservative

4. Conservative

16. Please indicate your annual family income.

$$
\begin{array}{lr}
\text { under } \$ 15,000 \_\$ 15,001-\$ 30,000 \\
\$ 45,001-\$ 60,000 \_\$ 60,001-\$ 70,000
\end{array}
$$

$\$ 30,001-\$ 45,000$

Above $\$ 71,000$ 
17. Have you ever served on a civil or criminal jury?

$$
\begin{array}{ll}
\text { 1. } & \text { Yes, Civil } \\
\text { 2. } & \text { Yes, Criminal } \\
\text { 3. } & \text { No, Never }
\end{array}
$$

18. Have you ever been a party in a lawsuit?
1. Yes, I have sued someone
2. Yes, I have been sued
3. Yes, I have both sued someone and been sued
4. No, I have never been involved 


\section{Appendix D}

Figure 1

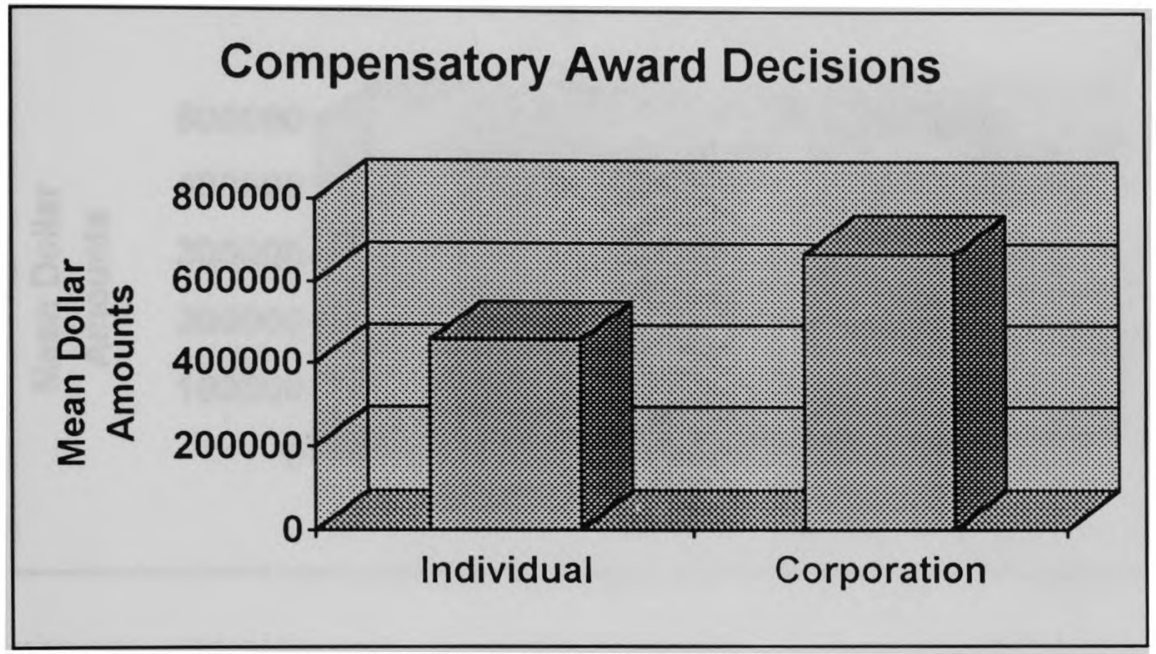

Figure 2

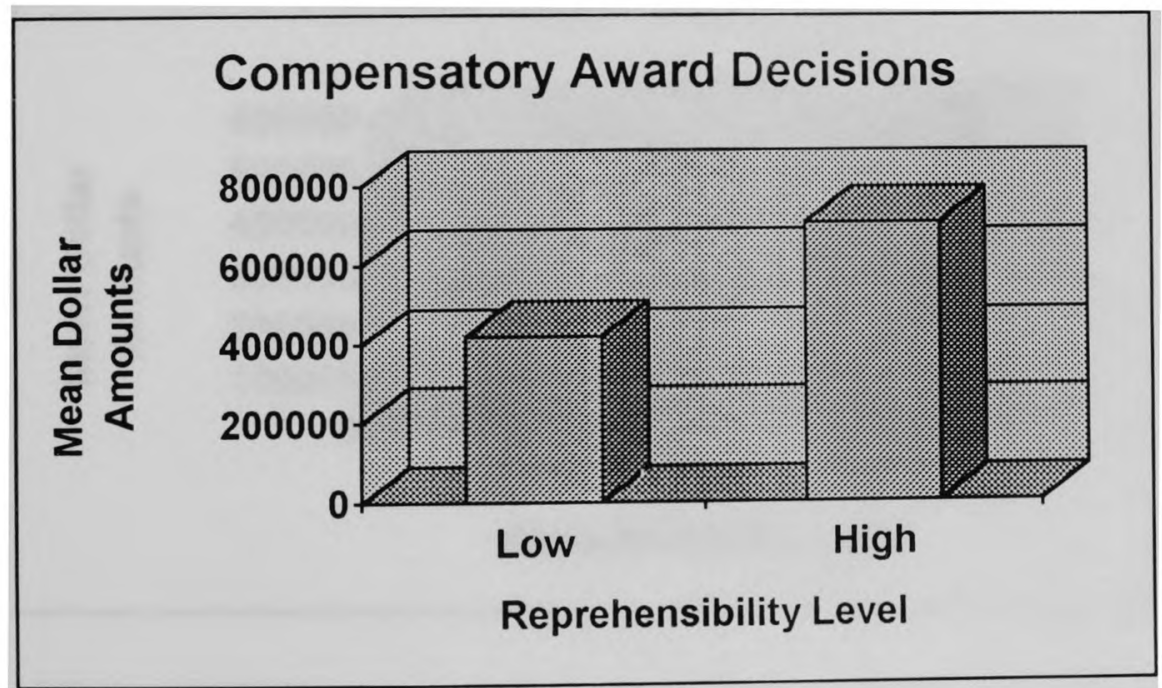


Figure 3

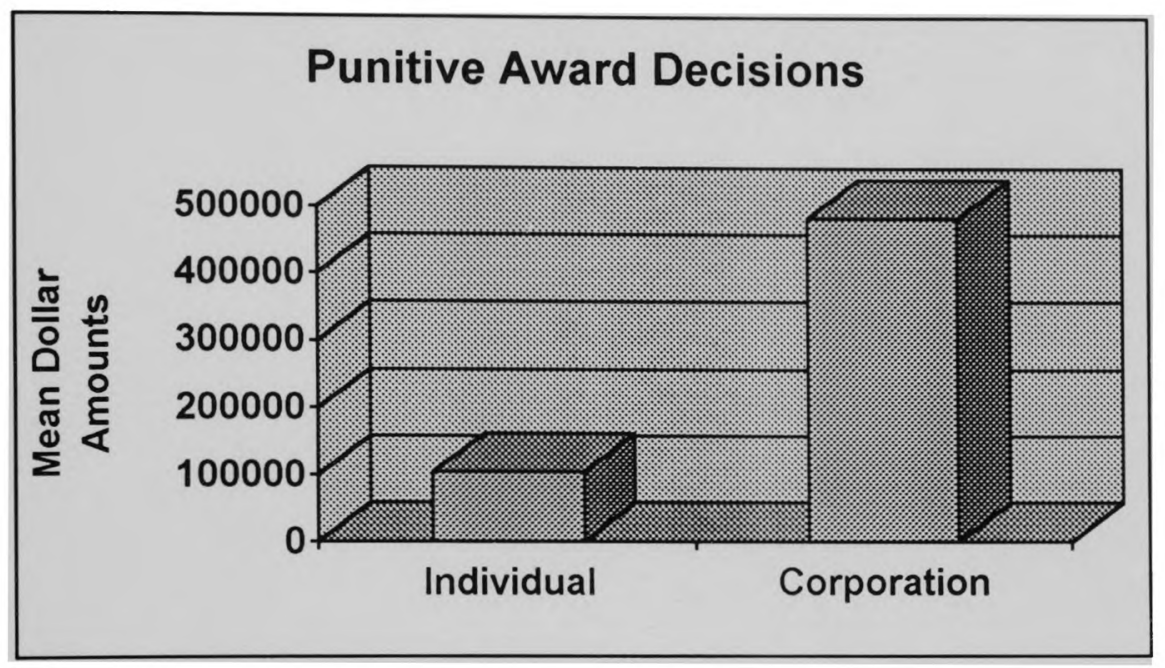

Figure 4

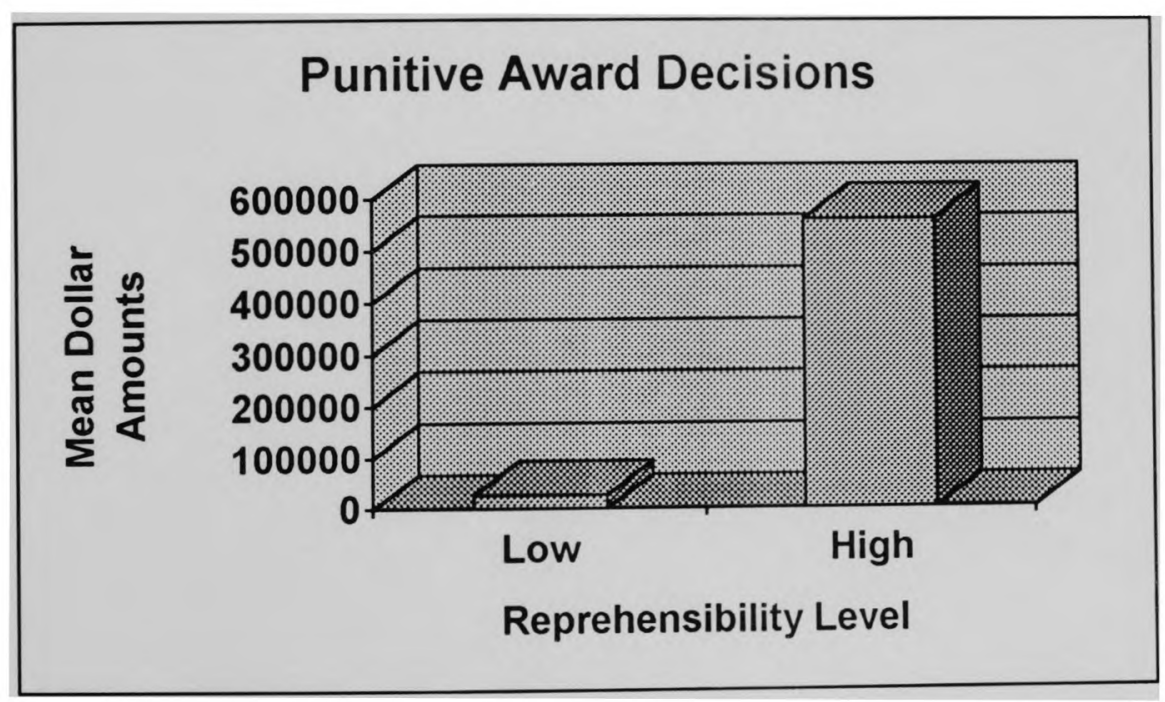

